FIU Law Review

Spring 2008

\title{
Gender, Place, Discursive Space: Where is Same-Sex Marriage?
}

Marc R. Poirier

Seton Hall University School of Law

Follow this and additional works at: https://ecollections.law.fiu.edu/lawreview

Part of the Other Law Commons

Online ISSN: 2643-7759

Recommended Citation

Marc R. Poirier, Gender, Place, Discursive Space: Where is Same-Sex Marriage?, 3 FIU L. Rev. 307 (2008).

DOI: https://dx.doi.org/10.25148/lawrev.3.2.6

This Symposium is brought to you for free and open access by eCollections. It has been accepted for inclusion in FIU Law Review by an authorized editor of eCollections. For more information, please contact lisdavis@fiu.edu. 


\title{
Gender, Place, Discursive Space: Where is Same-Sex Marriage?
}

\author{
Marc R. Poirier ${ }^{1}$
}

\section{INTRODUCTION}

At the opening dinner for LatCrit XII, the speakers discussed the local racial geopolitics of Miami-Cubans, Haitians, Jews, other Latino groups, white southern Protestants. Meanwhile, a dinner companion passed me a note that asked, "Is race public or private?" I wrote back, "It's both. Race is performed, for self and others." He wrote back, "I thought you'd say that."

My scholarship increasingly focuses on another part of our constellation of identities: gender, including GLBT identity, especially in its performative aspects. It specifically considers how performances of transgressive or stigmatized identity around sex and gender have the potential to transform, at one and the same time, (1) an individual's sense of identity around sex and gender, (2) the character of specific spaces and places, (3) social norms of identity around sex and gender, and (4) the legal rules in specific jurisdictions. I will summarize some past efforts here, sketch a couple of current projects, and raise some questions. I take seriously the symposium organizers' admonition that this piece is to reflect the LatCrit conference presentation and that it need not offer the intense footnote apparatus customary in law review scholarship.

This essay addresses gender as performance (Part I); the concepts of place and discursive space, especially as concerns the visibility of GLBT individuals and issues (Part II); and some of the ways one could address the question "Where is same-sex marriage?" in light of the preceding discussions (Part III). Part IV offers some concluding thoughts on the usefulness of the method demonstrated in this essay, that is, asking the place/space question when considering contested and stigmatized identities.

1 Professor of Law, Seton Hall University School of Law. Versions of the paper were also presented at a Seton Hall Law School Faculty Colloquium and at a New York Area LGTB Writers Workshop. Thanks to Martin Bruner for a helpful conversation about the thesis and structure of these comments and to Michael Poreda for reviewing the draft. Thanks to research assistants John Devendorf, Michelle Ghali, and Michael Poreda for all of their research assistance. 


\section{GENDER}

My previous work in the area of gender has considered everyday mechanisms of the creation and maintenance of gender roles and gendertagged social categories generally; the emergence of public discussions about masculinity vis-à-vis homosexuality, especially when the Boy Scouts of America are concerned; the importance of piecemeal normalizing performances of various social roles by GLBT individuals and same-sex couples in preparing the way for the cause of marriage equality; and the potential for transgressive performances of gender roles to shift social and cultural norms around gender, including norms around marriage. I will summarize some of this work here.

In a symposium article a few years back about cognitive theory, gender, and gender-tagged social roles (occupations, family, politics), I stressed that gender stereotypes are grounded in the visible repetition of microperformances of gendered social roles. ${ }^{2}$ Stereotypical gender roles exist at the level of individual human bodies and consciousnesses. They are perceived, stored in cognitive categories, and replicated in daily performances, iteratively, much in the way a language is. ${ }^{3}$ Normally, this iterated and diffuse reproduction results in a kind of homeostasis that preserves the alreadyestablished norms and stereotypes. However, I suggested that by shifting both the gender of examples encountered in the real world and the gender of media images of persons in various social roles, it might be possible to undermine the cultural and cognitive reproduction of unconscious gender stereotypes, and change the contents of our categories bit by bit. ${ }^{4}$ A small section of a subsequent article on cognitive bias reiterated this theme of the role of visibility of workplace performances of gendered occupational roles in creating and maintaining gender stereotypes, arguing that the owners of

2 Marc R. Poirier, Gender Stereotypes at Work, 65 BROOK. L. REV. 1073, 1076, 1093-1116 (1999). This article was developed as part of a symposium panel on ViRGINIA VALIAN, WHY SO SLOW? THE ADVANCEMENT OF WoMEN (1998) and in particular develops Dr. Valian's discussion of gender schemas.

3 Poirier, supra note 2, at 1108-10; $c f$. Steven L. Winter, The "Power" Thing, 82 VA. L. REv. 721, 805-09 (1996) (discussing the diffuse replication of gender roles).

4 The "content of our categories" refers to a leading law review article in the field of cognitive bias and law, Linda Hamilton Krieger, The Content of Our Categories: A Cognitive Bias Approach to Discrimination and Equal Employment Opportunity, 47 STAN. L. REV. 1161 (1995). I explored briefly the hypothetical example of a community where most of the bus drivers are female. Children in such a community might well not acquire an unconscious gender-tag for the occupation bus driver, or might acquire a female gender-tag for the occupation bus driver. On the other hand, if the images available in the media continue to be of male bus drivers, it is not so certain whether and how the occupation will be tagged for gender. Poirier, supra note 2, at 1097-98. The potential for changing unconscious stereotypes by changing images is discussed $i d$. at 1120-21. 
workplaces should be held responsible in some measure to control the sites of reproduction of disadvantageous gender stereotypes. ${ }^{5}$

In an article about another arena of specifically male gender performance, I considered the politics of American masculinity and the Boy Scouts of America's ban on openly gay adult members. ${ }^{6}$ Although the Supreme Court upheld this ban as a matter of freedom of expressive association in Boy Scouts of America v. Dale, ${ }^{7}$ the article takes a curiously positive view of the case. The controversy forced the Boy Scouts' anti-gay policy out into the open. And because of the pervasive and culturally important nature of the Boy Scouts in the United States, the controversy forced a debate on youth education, masculinity, and homosexuality, including the stigmatization of "sissies" and the heteronorming of male gender role models, into many local corners of American society that frankly would probably have preferred not to have to go there. ${ }^{8}$ The Boy Scouts/gay-exclusion controversy made the social construction of masculinity in this context much more apparent to those who cared to notice. I argued moreover that the many sites of local contest generated by the Boy Scouts' gay-exclusion controversy were places where social change around masculinity could begin, once the de-essentialization of masculinity had occurred." "Indeed, because gender is performed, produced, and reproduced in individual interactions, the local and personal level is where change must ultimately occur, if a change mandated via larger normative structures within our society, such as statutory or case law, is to take hold."

The investigation of local and personal interaction around gender performance and its relationship to facilitating cultural changes at the legal level was continued in an article published early in $2007^{11}$ on the occasion of Lewis v. Harris, ${ }^{12}$ the New Jersey marriage equality decision. Lewis $v$. Harris required the state to provide rights and benefits to same-sex couples equal to those available to married couples, but allowed the legislature to decide whether to permit same-sex marriage or instead create an alternate legal structure for same couples. The first part of that article, relying on decades of historical and legal scholarship by others about the emergence of gay and lesbian movements and legal claims, demonstrated that a standard,

\footnotetext{
5 Marc R. Poirier, Is Cognitive Bias at Work a Dangerous Condition on Land?, 7 EMP. RTS. \& EMP. POL'Y J. 459, 491-94 (2003).

6 Marc R. Poirier, Hastening the Kulturkampf: Boy Scouts of America v. Dale and the Politics of American Masculinity, 12 LAW \& SEX. 271 (2003).

Boy Scouts of Am. v. Dale, 530 U.S. 640 (2000).

Poirier, supra note 6, at 275-76.

Id. at 275 .

10 Id.

11 Marc R. Poirier, Piecemeal and Wholesale Approaches Towards Marriage Equality in New Jersey: Is Lewis v. Harris a Dead End or Just a Detour?, 59 RuTGERS L. REV. 291 (2007).

12 Lewis v. Harris, 908 A.2d 196 (N.J. 2006).
} 
well-accepted trajectory for GLBT folk also occurred in New Jersey, from stigmatized to tolerated to recognized as valuable participants in society in other words, the gradual emergence of GLBT folk into visibility without shame, first as individuals and then as couples and parents. ${ }^{13}$ Eventually a claim of a right to legal recognition as couples - the type of claim only partially successful in Lewis v. Harris — could be plausibly advanced. I summarized:

The basic engine of the piecemeal approach to wholesale recognition [of same-sex marriage] is an ever-increasing visibility of GLBT folks as normal, functional, decent human beings, capable of having normal, functional, decent familial relationships. It allows many people (both in the general population and in the legislature and judiciary) who may have been unfamiliar with GLBT folks to "get used to it," in the words of a well known queer slogan. "Getting used to it" takes the form of looking at a particular same-sex couple or same-sex parentchild relationship in a particular context and saying, "Well, that looks pretty healthy and normal, all things considered," over and over again. Essentially, it involves GLBT folks' socially visible performances as couples and parents, which gradually normalize their cultural status as acceptable couples and parents ....

As Carlos Ball recently argued, "in many ways, overcoming invisibility is the first step in successfully demanding basic civil rights." 15 And with regard to same-sex marriage, once visibility becomes possible, then, as Andrew Koppelman argues, performances of same-sex couples as normal couples and parents can potentially persuade people that GLBT folk are equals and deserve equal treatment legally. ${ }^{16}$

Lastly, in a recent article seeking to understand the same-sex marriage controversy better from the traditionalist point of view, ${ }^{17} \mathrm{I}$ argued, inter alia, that same-sex couples transgress traditionalist cultural norms in their daily microperformances as couples and parents. Thus, the injury attributed to same-sex marriage, from the traditionalist viewpoint, is not only the dilution, desecration, tarnishment, and pollution of the traditional ritual and legal status of marriage in the general and abstract, but also the imposition on traditionalists in their daily lives of a myriad of visible, transgressive

13 Poirier, supra note 11.

14 Id. at 344.

15 Carlos A. Ball, The Backlash Thesis and Same Sex Marriage: Learning from Brown v. Board and Its Aftermath, 14 WM. \& MARY BiLL OF RTS. J. 1493, 1534 (2006).

16 Andrew Koppelman, The Decline and Fall of the Case Against Same Sex Marriage, 2 U. ST. ThOMAS L.J. 5, 11 (2004) (noting the persuasiveness of performances of same-sex couples and parents as the equivalent of their heterosexual counterparts).

17 Marc R. Poirier, The Cultural Property Claim within the Same Sex Marriage Controversy, 17 COLUM. J. GENDER \& LAW 343 (2008). 
microperformances of same-sex couples as married couples. Relying principally on Mary Anne Case, ${ }^{18}$ Marc Fajer, ${ }^{19}$ and Mae Kuykendall, ${ }^{20}$ as well as on an analysis of the problematic lesbian marriage in Shahar v. Bowers, ${ }^{21}$ I argue that same-sex couples are troubling for traditionalists in part because their daily visible performances as couples fail to follow the traditional, heteronormative structures and strictures of sexuality, gender, and family. These inhere in traditional marriage and traditionalists view them as central to the reproduction of fundamental social structures and identities from one generation to the next.

\section{Visibility, Place, AND DiscuRsiVE SPACE}

Gender, understood in this way, inevitably implicates local iterated performances. For this reason, a vital part of the Kulturkampf over samesex marriage, and over gender and sexuality more generally, is the control of visibility. GLBT equality is achieved in significant measure through transgressive visibility. Those who wish to impede GLBT equality do so in part through limiting GLBT visibility. GLBT performances of identity occur in physical places and also in what I will call discursive spaces. Physical places require little explanation. We could think of a "discursive space" as a realm where interpersonal contact and expression can occur and be expressed, whether in physical places or facilitated by speech or any of a number of media. Physical place and discursive space often overlap, but they are not the same thing.

Here is an example. Madhavi Sunder's perceptive analysis of the conflict around a gay and lesbian group's attempted participation, under an explicit banner, in the Boston St. Patrick's Day Parade ${ }^{22}$ describes the conflict as about "access to discursive space." 23 Sunder distinguishes an earlier era of civil rights which demanded access to physical space from a new

18 See generally Mary Anne Case, Couples and Coupling in the Public Sphere: A Comment on the Legal History of Litigating for Lesbian and Gay Rights, 79 VA. L. REV. 1643 (1993).

19 See generally Marc A. Fajer, Can Two Real Men Eat Quiche Together? Storytelling, GenderRole Stereotypes, and Legal Protection for Lesbians and Gay Men, 46 U. MIAMI L. REV. 511 (1992).

20 See generally Mae Kuykendall, Resistance to Same-Sex Marriage as a Story about Language: Linguistic Failure and the Priority of a Living Language, 34 HARV. C.R.-C.L. L. REV. 385 (1999).

21 Shahar v. Bowers, 114 F.3d 1097 (11 ${ }^{\text {th }}$ Cir. 1997) (en banc) (6-5 decision upholding Georgia Attorney General's rescission of offer of employment as an attorney to a law student who engaged in a same-sex wedding in the Jewish Reconstructionist faith and thereafter held herself out as married in her faith). See Part III.D. infra for further discussion of this case.

22 This conflict is the subject of Hurley v. Irish-American Gay, Lesbian, and Bisexual Group of Boston, 515 U.S. 557 (1995) (application of state public accommodation law that would alter the expressive content of a parade by requiring visible inclusion of a gay and lesbian group violated the parade organizers' First Amendment rights).

23 Madhavi Sunder, Note, Authorship and Autonomy as Rites of Exclusion: The Intellectual Propertization of Free Speech in Hurley v. Irish-American Gay, Lesbian and Bisexual Group of Boston, 49 STAN. L. REV. 143, 144 (1995). 
demand for access to cultural space in order to create and contest social meaning. ${ }^{24}$ I would not move so quickly to dismiss the dimension of access to physical space, as part of the demand for cultural space. Indeed, a recent formulation by Sunder is broader. Both physical and cultural space are recognized as important dimensions of struggle. ${ }^{25}$

Traditionalist groups well understand that they need to exercise control over the visibility of transgressive performances in the places and spaces that they control. Familiar examples include the military's gay-exclusion policy, currently articulated as "Don't Ask, Don't Tell"; the Boy Scouts gay-exclusion policy; and the American Catholic Bishops' articulation of a semi-closeted role for GLB folk within the Catholic fold. ${ }^{26}$ From the opposite viewpoint, consider what a number of American law schools attempted to do in their unsuccessful lawsuit in Rumsfeld v. FAIR, ${ }^{27}$ seeking to bar physical access to law schools on the basis of rights of expressive association and free speech, in connection with the law schools' antidiscrimination policies. $^{28}$ Madhavi Sunder has a word for it. Institutions can occupy physical places and those places can become contested because they pro-

24 “Today, civil rights movements' priorities have shifted from obtaining access to physical space to seeking access to discursive space. A new struggle for inclusion by groups such as gays and lesbians centers on issues of identity, voice, culture, and ultimately the power to create and contest social meaning." Id. at 145 (footnote omitted).

25 Sunder wrote recently, "The freedom and equality battles of this new century will not only be about access to physical space, but also to discursive space. The crucial question will be: who will have power to make our cultural world?" Madhavi Sunder, $I P^{3}$, 59 STAN. L. REV. 247, 321 (2006).

26 Poirier, supra note 11, at 343-44 (discussing the military's ban on openly gay and lesbian personnel; the Boy Scouts' exclusion of gay scoutmasters; and the Catholic church's recent pronouncements, in a 2006 statement, United States Conference of Catholic Bishops, Ministry to Persons with a Homosexual Inclination: Guidelines for Pastoral Care (November, 2006), available at http://www.nccbuscc.org/dpp/Ministry.pdf). For thoughtful explorations of the mechanisms and extent of the silencing and invisibility imposed on GLBT service personnel by the "Don't Ask, Don't Tell" policy, see, for example, Tobias Barrington Wolff, Political Representation and Accountability under Don't Ask, Don't Tell, 89 Iowa L. REv. 1633 (2004); Kenji Yoshino, The Assimilationist Bias in Equal Protection: The Visibility Presumption and the Case of "Don't Ask, Don't Tell," 108 YALE L.J. 485, 53857 (1998).

27 Rumsfeld v. Forum for Academic and Institutional Rights, Inc., 547 U.S. 47 (2006).

28 With the polarities reversed, Georgetown University, both as an academic institution and as a religious one, was motivated by the same concerns in a case involving whether recognition and support of two gay and lesbian student groups would violate the institution's constitutional rights. Compare Gay Rights Coalition of Georgetown University Law Center v. Georgetown University, 536 A.2d 1, 20-39 (D.C. Ct. App. 1987) (en banc) (plurality opinion by Mack, J.) (distinguishing endorsement from provision of tangible benefits, interpreting the District of Columbia Human Rights Act to require provision of tangible benefits but not of endorsement, and finding that precisely because the Act does not require endorsement, it is not an impermissible burden on the university's free exercise of religion to require provision of tangible benefits) with id. at 62, 68-74 (Belson, J., concurring in part and dissenting in part) (arguing that forcing the university to subsidize speech with which it disagrees by providing tangible benefits to the group violates its First Amendment rights, quite apart from the issue of endorsement). 
vide, in Sunder's term, "discursive spaces." 29 Cultural conflict over individual identity and shared cultural meanings and values occurs in specific places, over specific discursive spaces.

"Place" is sometimes used in the law when what is really at issue might be better described as discursive space. For example, New Jersey's Law Against Discrimination (LAD) prohibits discrimination in a "place of public accommodation," and identifies a number of protected identity categories. ${ }^{30}$ As to what constitutes a "place," the statute provides a long, nonexclusive list. ${ }^{31}$ In a 1974 case, the Little League tried unsuccessfully to defend against a lawsuit challenging its exclusion of girls from youth baseball, on the basis that the Little League did not operate from any fixed parcel of real estate which it owned and operated. ${ }^{32}$ It argued that there simply was no "place" of public accommodation so as to trigger the public accommodation law. The appellate court rejected this argument, pointing out that the Little League's activities occurred on various ball fields, even if not ones owned by the Little League. ${ }^{33}$ The Little League was moreover held to be a "public accommodation" because the invitation was open to all (boy) children. $^{34}$ I would describe what the opinion is getting at as the way in which public gatherings (which must occur in a physical place, after all) constitute discursive spaces in which community is expressed and recreated. ${ }^{35}$ Although there must be places for those gatherings, the issue is admission to/exclusion from those spaces and to the organizations that construct them.

The same "place of public accommodation" issue was argued to the New Jersey courts in the Boy Scouts gay-exclusion controversy. ${ }^{36}$ The Boy Scouts claimed that the LAD did not apply to their organization as they owned no "place" and could not therefore be deemed a "place of public accommodation." 37 The New Jersey Supreme Court "decline[d]...to construe 'place' so as to include only membership associations that are connected to a particular geographic location or facility." ${ }^{, 38}$ The court then held

29 I am not especially satisfied with the term, frankly. I find "discursive space" used in a variety of contexts, some of them seemingly quite vapid. Nevertheless, I have not found any other usage to be consistent across disciplines, either. For now I will stick with "discursive space."

30 N.J. STAT. ANN. § 10:5-4 (2002).

31 N.J. STAT. ANN. § 10:5-5 (2002).

32 Nat'l Org. for Women, Essex County Chapter v. Little League Baseball, 318 A.2d 33, 37 (N.J. Sup. Ct. App. Div. 1974).

33 Id. at 37.

34 Id. at $37-38$.

35 To be sure, access to a common place or space may also be about access to tangible benefits. Herein of separate but equal, a topic well beyond the scope of this essay.

36 Dale v. Boy Scouts of Am., 734 A.2d 1196 (N.J. 1999), rev'd, 530 U.S. 640 (2000).

37 Id. at 1208-10 (N.J. 1999).

38 Id. at 1210. 
that the Boy Scouts was, in addition to a place, a public accommodation. ${ }^{39}$ Therefore, unless a statutory exception or constitutional prohibition applied, the LAD barred the Boy Scouts from excluding Mr. Dale for being an avowed homosexual.

In its discussion of the first principal factor addressing public accommodation status - whether the entity engages in broad public solicitationthe New Jersey Supreme Court wrote a passage that is especially resonant with the themes of local and personal public performance of identity:

Boy Scout troops also take part in perhaps the most powerful invitation of all, albeit an implied one: the symbolic invitation extended by a Boy Scout each time he wears his uniform in public.... A boy in a uniform may well be Boy Scouts' strongest recruiting tool. By encouraging scouts to wear their uniforms to school, and when participating in "School Nights" and public demonstrations, Boy Scouts invites the curiosity and awareness of others in the community. Boy Scouts admits that it encourages these displays in the hope of attracting new members. 40

The Boy Scout uniform is understood to constitute an advertisement for the organization, as well as functioning as clothing. Through the bodies of its child members, dressed to signal their membership, the Boy Scouts extends advertisement for the organization into specific locations that make up public spheres. According to the New Jersey Supreme Court, this is a major part of what makes the organization public.

On certiorari, the United States Supreme Court could not reverse the state supreme court's interpretation of the LAD, a matter of state law. ${ }^{41}$ It went out of its way to comment on New Jersey's extremely broad reading of place of public accommodation, and pointed out that several other courts had ruled that the Boy Scouts were not a place of public accommodation. ${ }^{42}$ New Jersey's position was unique.

The Boy Scouts case offers the opportunity for some other important reflections on place and discursive space in conflicts around identity involving sex and gender. James Dale, the plaintiff, tried unsuccessfully to manage a separation of different discursive spaces in which his identity was at issue. He came out as gay while an undergraduate at Rutgers, became copresident of the Rutgers University Lesbian/Gay Alliance, and appeared in a photograph in an interview in a statewide newspaper, the (Newark) Star-

39 Id. at 1210-13. The test applied asked "whether the entity . . . engages in broad public solicitation, whether it maintains close relationships with the government or other public accommodations, or whether it is similar to enumerated or other previously recognized public accommodations." Id. at 1210.

$40 \quad$ Id. at 1211.

41 Boy Scouts of Am. v. Dale, 530 U.S. 640 (2000).

42 Id. at 657. 
Ledger. ${ }^{43}$ Yet, he never ever identified himself as gay while in any physical place or space controlled by the Boy Scouts. ${ }^{44}$ In contrast to the GLIB group in Hurley, Dale did not seek to proclaim his gay identity within the physical places and discursive space of the Boy Scouts organization. ${ }^{45}$ Nevertheless, having become visible somewhere in the broad public sphere as a gay man, he was not permitted thereafter to avoid the consequences of the Boy Scouts' concern by continuing his practice of concealing his gay identity within the confines of the Boy Scouts places and spaces. He was not permitted to rely on a separation of discursive spaces.

The rhetoric in the United States Supreme Court's discussion on this point is telling. ${ }^{46}$ Although in one sense the issue was Dale's membership in the Boy Scouts, the Court repeatedly discusses the issue in terms of Dale's "presence" in the organization, using the image of communicative "presence" of the body no less than four times. ${ }^{47}$ This may be partly due to the precedential pull of the facts in Hurley, where the GLIB organization really did intend its physical presence, with an identifying banner, in a public parade, to communicate something. ${ }^{48}$ The particularly strong valence of physical presence as communication is evident in the last of the uses of "presence" in Dale. ${ }^{49}$ In response to the argument that the Boy Scouts was inconsistent in allowing heterosexual adults who disagreed with the gayexclusion policy to remain within the organization, while excluding Dale, the Court writes:

The presence of an avowed homosexual and gay rights activist in an assistant scoutmaster's uniform sends a distinctly different message from the presence of a heterosexual assistant scoutmaster who is on record as disagreeing with Boy Scouts policy. The Boy Scouts has a First Amendment right to choose to send one message but not the other. ${ }^{50}$

43 Dale, 734 A.2d. at 1204-05; Dale, 530 U.S. at 644-45.

44 Dale, 734 A.2d at 1205-05, 1225, 1229; Dale, 530 U.S. at 689-90 (Stevens., J., dissenting).

45 Dale, 734 A.2d at $1225,1229$.

6 Dale, 530 U.S. at 653-56.

47 The first three of these are as follows. "We must then determine whether Dale's presence as an assistant scoutmaster would significantly burden the Boy Scouts' desire to not 'promote homosexual conduct as a legitimate form of behavior...." Id. at 653. "Dale's presence in the Boy Scouts would, at the very least, force the organization to send a message ...." Id. "[T] $]$ he presence of Dale as an assistant scoutmaster would just as surely interfere with the Boy Scouts' choice not to propound a point of view contrary to its beliefs." Id. at 654. Justice Stevens' dissent is also quite clear that the majority's opinion rests on communicative presence, not on the possibility that Dale might become an open advocate of gay causes at those times and places where he is being a Boy Scout. Id. at 689-93 (Stevens, J., dissenting).

48 The dissent distinguishes Hurley's physical inclusion in parade issue from Dale's inclusion in membership issue. Id. at 693-95 (Stevens, J., dissenting).

49 Id. at 655-56 (majority opinion).

50 Id. 
First, we might note the reappearance of the Boy Scout uniform theme. The Court clearly understands that the uniform conveys a message that is about personal identity and affiliation with the organization at the same time. But, because Dale is an "avowed homosexual," his own body is already marked. ${ }^{51}$ It conveys a message by its very "presence" within the Boy Scouts space. This message is at odds with the message represented by the uniform Dale wears.

Second, the Court distinguishes between the verbal message of a heterosexual dissenter who is an adult member of the Boy Scouts and the physical message of the presence of an avowed homosexual. The quoted passage recognizes that two different types of communication are occurring. One is about ideas and is verbal, and the other is about identity and is communicated by physical presence. What is more, the Court gives the Boy Scouts the upper hand by allowing it to choose which messages to allow its members to send out (the verbal ones, not the physical presence ones) and what degree of dissent to tolerate.

Third, the U.S. Supreme Court's disagreement with the New Jersey Supreme Court is rooted precisely in a disagreement over whether the mere presence of Mr. Dale interferes with the Boy Scouts' message. ${ }^{52}$ It is only because the Supreme Court has determined that the forced inclusion of Mr. Dale via the public accommodations law runs afoul of the Boy Scouts' desired message that the Court reaches the First Amendment issue at all. ${ }^{53}$

In some other respects, the Supreme Court's approach to management of discursive space in Dale is important to mention, but does not require so much discussion. The Court essentially defers to the Boy Scouts as to what the organization's message is without dealing with the problem of very scanty historical evidence. It also essentially defers to the management of the Boy Scouts as to what constitutes interference with its message. And the Court refuses to investigate whether dissent and disagreement within the organization - for example, a troop-by-troop local option - has any place. ${ }^{54}$

Ultimately, as Christopher Hargis points out about Dale:

51 Justice Stevens in dissent is puzzled and troubled. "The only apparent explanation for the majority's holding, then, is that homosexuals are simply so different from the rest of society that their presence alone-unlike any other individual's_-should be singled out for special First Amendment treatment. Under the majority's reasoning, an openly gay male is irreversibly affixed with the label 'homosexual.' That label, even though unseen, communicates a message that permits his exclusion wherever he goes. His openness is the sole and sufficient justification for his ostracism." Id. at 696 (Stevens, J., dissenting). See generally Christopher S. Hargis, Note, The Scarlet Letter " $H$ ": The Brand Left after Dale, 11 LAw \& SEX. 209, 224-40 (2002); Nancy J. Knauer, "Simply So Different": The Uniquely Expressive Character of the Openly Gay Individual after Boy Scouts of America v. Dale, 89 KY. L.J. 997 (2000-2001).

52 Dale, 530 U.S. at 654-56.

53 Id. at 656.

54 See generally Madhavi Sunder, Cultural Dissent, 54 STAN. L. REV. 495 (2001). 
[T] he majority rests its decision on the right of a speaker to control his or her message, while the majority itself simultaneously takes away that control by sua sponte constructing and imposing expressive elements upon homosexual identity. Despite the rhetoric of a state's inability to "interfere with speech," the Court is the player who runs ultimate interference.

Hargis argues that by framing homosexuality as having elements of both status and expression, the Court constructs the issue as a battle between the First Amendment rights of opposed groups, rather than as the exclusion of a historically stigmatized and statutorily protected group. ${ }^{56}$ Hargis contrasts the Court's approach to discrimination based on race and gender and its approach to homosexuality. ${ }^{57}$ In contrast to its historic sympathy for groups "clamoring for equality on race or gender grounds," the Court "shifts dramatically when homosexuals attempt to claim the same discursive space."

\section{WHERE IS SAME-SEX MARRIAGE?}

Because performance and visibility occur in specific places and spaces, we may want to ask, "Where is same-sex marriage? Where specifically in place and space?" I sketch here some of the possibilities that this question evokes. A taxonomy structures my responses. One might approach the question in terms of territorial jurisdiction (at any level of scale); aterritorial nomos (again, at any level of scale); metonymy (substituting "Where's the wedding?" for "Where's the marriage?"); and microperformances of the status of being married.

\section{A. The Territorial Jurisdiction Approach}

One answer to the question "Where is same-sex marriage?" is straightforward: "Massachusetts, Connecticut, and until recently California." Variant one of this answer includes states with marriage substitutes - currently, the all-but-in-name civil unions in Vermont, New Jersey, and New Hampshire and the all-but-in-name domestic partnerships in Oregon, Washington state and California (the prior domestic partnership statute survives

55 Hargis, supra note 51, at 241.

56 Id. at 240.

57 With regards for example to racial matters, Rosa Parks' black body located in the wrong part of the bus is every bit as much about expression as status, and in some ways is quite comparable to GLIB's attempt to enter the St. Patrick's Day parade or Dale's attempt to remain "present" in the Boy Scouts. But it is debatable whether our understanding of the nature of identity as performance has changed and become more sophisticated since the 1950s or — more likely in my view — the explanation is that homosexuality is simply a less favored category for constitutional protection and, therefore, a rhetoric justifying exclusion in terms of compelled speech and expressive association is more likely to succeed. So Hargis' position may well be an overstatement.

$58 \quad$ Id. at 237. 
the definition in California, via November 2008's Proposition 8, that only a marriage between a man and woman will be valid and recognized in California). Variant two adds the Netherlands, Belgium, Spain, Canada, South Africa, and Norway, all of which currently recognize same-sex marriage. A third variant includes the numerous jurisdictions outside the United States that have some other legal form that provides significant legal recognition to same-sex couples but falls short of marriage or marriage equivalence. Much of Western Europe is in this category, and perhaps some other territorial jurisdictions.

The structuring principle behind this response is that in an age of territorial jurisdictions, the where of marriage is about which jurisdictions recognize it and which do not. Fair enough, but certainly not the whole story. ${ }^{59}$ For one thing, one might ask why marriage in the United States is governed at the state level rather than another one. Surely this is partly an accident of our history; we began as a much more loosely knit union of entities with more clearly separate sovereignty. ${ }^{60}$ In addition to the historical starting point, Anne Dailey argues that states provide an appropriate balance between localist and communitarian concerns and a desire for some degree of uniformity. ${ }^{61}$

The state level is not the only possibility. For one thing, this is a country of dual sovereignty, state and federal. Disagreement over the legal definition of marriage can prompt attempts to move the issue to a federal level. This has happened repeatedly in our history. Ed Stein recently surveyed the various efforts to develop a federal constitutional approach to various aspects of marriage. ${ }^{62}$ With regard to same-sex marriage, we should note that the Federal Marriage Amendment, proposed in $2004,{ }^{63}$ was specifically

59 I explore some of the shortcomings of the territorial jurisdiction approach, especially when married to federalism, in Marc R. Poirier, Same-Sex Marriage, Identity Processes, and the Kulturkampf: Why Federalism Is Not the Main Event, 17 TEMPLE PoL. \& CIV. RTS. L. REV. 387 (2008). One thesis of this piece is that the standard "laboratory of the states" explanation for federalism (crystallized in New State Ice Co. v. Liebmann, 285 U.S. 262, 311 (1932) (Brandeis, J., dissenting)) is inadequate to describe the rationale and motivation of Kulturkampf controversies such as same-sex marriage. Instead, we need to conceptualize a kind of "beachhead federalism" in which proponents of opposed ideological points of view seek to impose a uniform solution, but because of varying political circumstances, have to settle for the time being on a state-by-state patchwork.

60 See Anne C. Dailey, Federalism and Families, 143 U. PA. L. REV. 1787, 1821 (1995). But see, e.g., Kristin A. Collins, Federalism's Fallacy: The Early Tradition of Federal Family Law and the Intervention of States' Rights, 26 CARDOZO L. REV. 1761, 1767-69 (2005) (arguing that federal participation in family law is evident from an early period and that the notion of a state sphere over family law is a contingent historical phenomenon).

61 Dailey, supra note 60, at 1876-77.

62 Edward Stein, Past and Present Proposed Amendments to the United States Constitution Regarding Marriage, 82 WASH. U.L.Q. 611 (2004).

63 There are actually several proposed versions of the contemporary Federal Marriage Amendment. See Stein, supra note 62 , at 613 n. 1. Stein leads his article off by quoting S.J. Res. $30,108^{\text {th }}$ Cong. (2004). 
prompted by the reaction to Massachusetts' decision to recognize same-sex marriage ${ }^{64}$ and to the wildcat marriages of early 2004, themselves prompted by the Massachusetts decision. ${ }^{65}$ The Federal Marriage Amendment would eliminate the possibility of same-sex marriage and, in some versions, would eliminate legal recognition of other structures similar to marriage. We should also take note of the 1996 federal Defense of Marriage Act, which articulated a one man and one woman definition of marriage for all federal laws, without imposing the definition on matters related to state law. ${ }^{66}$

Moving in terms of scale in the other direction, "Where is same-sex marriage?" might prompt us to consider that perhaps the scale of territorial jurisdiction for marriage is too large and that it could be local rather than state level. Richard Schragger has made this argument. ${ }^{67}$ Or we could go further, severing marriage definitions from territorial jurisdiction altogether through disestablishment. Churches and other ethical and moral institutions and communities would then be free to define licit marriages as they see fit. Since, however, marriage is also the vehicle for structuring a large number of social benefits and responsibilities, the state would probably still have to recognize some kind of household unit for a variety of legal purposes. ${ }^{68}$

As to territorial jurisdiction more generally, we could note the relevance of various other Kulturkampf-related disputes that can be addressed at various levels of federal, state, and local jurisdiction. At issue in Romer v. Evans, ${ }^{69}$ for example, was a state-level response to local pro-gay ordinances in Denver, Boulder, and Aspen, Colorado. ${ }^{70}$ The traditionalist opposition organized at the statewide level and enacted a broad state constitutional ban on any pro-gay legislation. Justice Scalia's dissent is quite clear about this territorial jurisdiction/scale dimension of the controversy. He argues that there is nothing constitutionally wrong with state level responses that disable municipal level responses; and, moreover, that there is

64 Goodridge v. Dep't of Public Health, 798 N.E.2d 941 (Mass. 2003). See Opinions of the Justices to the Senate, 802 N.E.2d 565 (Mass. 2004) (clarifying that only marriage, and not a civil union law, would satisfy the holding of Goodridge).

65 See, e.g., Dean E. Murphy, San Francisco Married 4,037 Same-Sex Pairs From 46 States, N.Y. TIMES, Mar. 18, 2004; Gay Weddings Halted, But Marriages Stand, WASH. Post, Apr. 21, 2004, at A11 (reporting the decision in Li v. State, No. 0430-0357, 2004 WL 1258167 (Or. Cir. Apr. 20, 2004) and reporting that 3,022 same-sex couples were married in Oregon between March 3, 2004 and April 20, 2004). Wildcat marriages also occurred in New York, New Jersey and New Mexico in the winter and spring of 2004.

661 U.S.C. $\S 7$ (1996). The federal definition intrudes into many matters of everyday life, as federal law may be controlling on issues such as pensions, military benefits, Social Security, and bankruptcy debts.

67 See, e.g., Richard C. Schragger, Cities as Constitutional Actors: The Case of Same-Sex Marriage, 21 VA. J. L. \& POL. 147 (2005).

68 See infra Part III.B.

69 Romer v. Evans, 517 U.S. 620 (1996).

70 Id. at 623-24 (describing the statewide amendment initiative as in large part a response to the municipal ordinances). 
nothing wrong with federal level responses, even constitutional responses, that disable state level responses on moral grounds. ${ }^{71}$

On the issue of scale of territorial jurisdiction and the Kulturkampf, one important post-Romer decision upholds a local initiative amendment reversing pro-gay gains at the city charter level. It can be read to be consistent with Romer precisely because the scale of the traditionalist political and legal response matches the scale of the pro-gay ordinances overturned by the charter amendment. ${ }^{72}$

State territorial jurisdiction over marriage and the current variation among states in legal recognition of same-sex relationships force us to engage questions of choice of law and conflicts of law. ${ }^{73}$ As Andrew Koppelman writes, "What makes the choice of law problem so difficult with respect to marriage questions is that both territorial and personal considerations are in play." ${ }^{, 74}$ The traditional marriage-recognition rule is place-based: the place of celebration, lex loci celebrationis. A public policy exception purportedly allows states to refuse to recognize same-sex marriages valid where celebrated. ${ }^{75}$ Conflicts are created by legal recognition of a marriage in one state and presence, within the territory of a non-recognizing state, either of the couple or of one member of the couple or of some other interest (children, property, a tort right) sufficient to trigger a conflict. The conflict is created either by simultaneous whereness ${ }^{76}$ of the marriage in multiple jurisdictions, or by physical movement of some sort from one jurisdiction to another. A same-sex couple legally recognized in one state might own property in another state. One or both might travel to another state,

71 Id. at 647-48 (Scalia, J., dissenting) (prohibition); id. at 648-51 (state level constitutional prohibitions of polygamy approved by Congress as a condition of statehood, and territorial imposition of a prohibition of polygamy by Congress).

72 Equal. Found. v. City of Cincinnati, 128 F.3d 286 (6th Cir. 1997). See especially id. at 296-99 (distinguishing the local action of Cincinnati voters from the action at a statewide level deemed impermissible in Romer).

73 For a recent lucid and accessible summary and a proposed principle for resolution, see generally Andrew Koppelman, SAme SEX, DifFEREnt States: When SAME-SEX MARRiages Cross State LINES (2006).

$74 \quad I d$. at 16.

75 See, e.g., id. at 17. Congress also apparently felt the need in 1996 to clarify the Full Faith and Credit obligation under the United States Constitution, to the effect that a state need not recognize a same-sex marriage legally valid in another state. 28 U.S.C. $\$ 1738 \mathrm{c}(2006)$.

76 "Whereness" is an awkward neologism, but the reader will know what I mean. The alternative is an unfamiliar but real word, "ubiety," which means the quality of have a whereness, a place. Ubiety deserves a wider use in legal academic discourse. While we are doing vocabulary, one antonym for ubiety is "nullibiety," which is typically defined as having the quality of existing nowhere. I don't like this last definition as it is easily confused with not existing at all, and glosses over the very, very interesting question of where something exists if it has no single place of existing. I suspect that there are different kinds of nullibiety. I am dubious about taking claims of nullibiety to mean really nowhere, as opposed to no one place, as I believe that for all practical purposes there is a material substrate grounds in time and place to everything. Thanks to my colleague Tim Glynn for ongoing discussions about this terminology. 
temporarily, for a vacation or on work assignment, or permanently, changing domicile. Or when a couple splits up, one might move to a nonrecognizing state in the hopes of protecting her/himself from divorce proceedings if the non-recognizing state also refused to undertake divorce as a matter of law or equity. Such a move could be undertaken to preserve property or to insulate a parent-child relationship from legal divorce. ${ }^{77}$ All of these possibilities are just beginning to be fought out in the courts with regard to same-sex marriage, though the legal academic community has been thinking and arguing about them since the Hawaii litigation of the early 1990s suggested that sooner or later these types of conflicts would arise. $^{78}$ To be sure, other types of controversies over interstate recognition of marriage, around divorce and interracial marriage, will provide precedent and insight.

Whatever the doctrinal moves and eventual resolutions of them, the problem is set up by a tension between an expectation that things within a territorial jurisdiction will stay put and therefore can be governed unproblematically by that territorial jurisdiction's law, and an expectation that a person's identity and status (and with them kinship relationships and some kinds of property rights and tort rights) will move with the person stably from jurisdiction to jurisdiction. Our basic intuition is that a person's whereness perhaps ought to have different consequences from real estate's whereness.

The problem is illustrated in a brief discussion by Robert Ellickson, responding to a proposal that in some circumstances parties ought to be able to contract for the property rights scheme that will govern their property, notwithstanding the law of the territorial jurisdiction in which the property is located. $^{79}$ Ellickson points out that many government policies are appro-

77 For an exploration of some of the different kinds of inter-territorial movement of same-sex couples and their possible legal consequences, see, e.g., KOPPELMAN, supra note 73, at 100-13 (distinguishing evasive marriages, migratory marriages, visitor marriages, and extraterritorial cases); Andrew Koppelman, Interstate Recognition of Same-Sex Marriages: A Handbook for Judges, 153 U.PA. L. REV. 2143 (2005) (same); Joseph William Singer, Same Sex Marriage, Full Faith and Credit, and the Evasion of Obligation, 1 STAN. J. CIV. RTS. \& CIV. LIB. 1 (2005); Tobias Barrington Wolff, Interest Analysis in Interjurisdictional Marriage Disputes, 153 U. PA. L. REV. 2215, 2218-40 (2005) (exploring various kinds of interjurisdictional marriage disputes and the types of interests states may have in these various types of disputes).

78 See, e.g., Andrew Koppelman, Same-Sex Marriage, Choice of Law, and Public Policy, 76 TEX. L. REV. 921 (1998); Larry Kramer, Same-Sex Marriage, Conflict of Laws, and the Unconstitutional Public Policy Exception, 106 YALE L.J. 1965 (1997); Seth Kreimer, Territoriality and Moral Dissensus: Thoughts on Abortion, Slavery, Gay Marriage and Family Values, 16 QUINNIPIAC L. REV. 161 (1996); Michael E. Solimine, Competitive Federalism and Interstate Recognition of Marriage, 32 CREIGHTON L. REV. 83 (1998).

79 Robert C. Ellickson, A Private Idaho in Greenwich Village?, 115 YALE L.J. POCKET PART 5 (2005) (responding to Abraham Bell \& Gideon Parchomovsky, Of Property and Federalism, 115 YALE L.J. PoCKet PART 1 (2005)). See Abraham Bell \& Gideon Parchomovsky, Of Property and Federalism, 115 YALE L.J. 72, 76-78, 87-88 (2005) (discussing how the Defense of Marriage Act and the Full Faith 
priately linked to a territory of the legal jurisdiction "to enhance the quality of the within-state physical, social, and moral environment." time, Ellickson acknowledged, "[1]ocation matters far less in legal relationships that are not land-based." Ellickson's view should not have to have its legal regime tied to each different jurisdiction in which it is physically present. ${ }^{82}$ But when explaining that a state should be able to resist "the importation of out-of-state law [because it] can interfere with a state's efforts to create a distinctive moral climate," 83 Ellickson gives as one example the compelled recognition by an unwilling state of an out-of-state same-sex marriage and its associated property rights, which he characterized as potentially "a threat to moral values" in the eyes of some citizens. ${ }^{84} \mathrm{He}$ calls this claim of recognition of a same-sex marriage- - here per Bell and Parchomovsky's proposal based in contractual choice, rather than a choice of lex loci celebrationis-an "importation of [an] out-of-state form[] of interpersonal status." ${ }^{85}$ Is status imported, like a thing? Under what circumstances would we want to approach control over status as belonging to each jurisdiction through which a person moves physically, instead of belonging in some more stable fashion to the individual whose status and identity are at stake? Moreover, we might wonder how the recognition of an out-of-state legal same-sex union affects a state's "moral climate" and "moral environment." Are concerns about "moral environment" even legitimate here, especially when balanced against countervailing policies and interests? Should it make a difference whether the individual's choice of status is expressed by contractual choice, choice of domicile, or voluntary but temporary mobility of the body into the territory of a jurisdiction?

Synthesizing various choice of law approaches to the problem of same-sex relationships in different states, Koppelman recommends relying

and Credit Clause affect the power of one state to recognize property rights derived from same-sex marriage or civil union, and how that affects states' competition to provide property regimes).

80 Ellickson, supra note 79, at 6; see also Marc R. Poirier, Federalism and Localism in Kelo and San Remo, in Private Property, Community DeVElopment, AND EMINENT Domain 101 (Robin Paul Malloy ed., 2008) (arguing that property and land use matters have an ineluctable local component arising in party from the whereness (ubiety) of the res involved, land).

81 Ellickson, supra note 79, at 6.

82 Id. In a bizarre and perhaps inadvertent but telling pun, Ellickson describes the corporation as "not grounded." Unlike land. Hmmm. Moreover, although he suggests that the corporation's existence is virtual, he then ties its existence to Delaware, a territorial jurisdiction. Much needs to be unpacked here.

83 Id. at 7.

84 Id.

85 Id.

86 For some of my own thoughts on this congestion question, see Poirier, Cultural Property, supra note 17 (exploring the traditionalist experience of both legal recognition and physical presence of same-sex marriages as desecrating and polluting). See also John Copeland Nagle, Moral Nuisances, 50 EMORY L.J. 265 (2001). 
principally on domicile, the one place where a couple makes their home. ${ }^{87}$ The place-of-celebration rule must give way to a contrary strong state policy where a couple is domiciled not in the state of the place of celebration, but in another state that is opposed to legal recognition of same-sex marriage, and where the couple simply goes to a more friendly state long enough to celebrate the marriage. At the same time, a spouse's or couple's merely transitory presence in a non-recognizing state should not invalidate an otherwise valid same-sex marriage. ${ }^{88}$ Koppelman's recommendation fine-tunes the effect of a couple's mobility and of the lex loci celebrationis rule, relying for its touchstone on the human commitment to live in one predictable place that constitutes domicile. In fact, I suspect that it helps the persuasiveness of his argument that we can imagine a house ("domicile" is related to the Latin word for house, domus) belonging to the couple, a house physically located in the territory whose law governs the couple's status-even if they have no house.

One consequence of relying on domicile, a relatively stable category and one with ubiety, is to permit individuals and couples, through their choice of domicile, cumulatively to constitute particular place-based communities with particular approaches towards same-sex marriage, as well as other parts of the Kulturkampf. The relative permanence of domicile prevents the undermining of community-building consequences of these locational choices by particular couples' temporary mobility to a different locus celebrationis.

At the same time, Koppelman's proposal permits the interstate mobility of persons and interests necessary to function in contemporary society, without undermining the status chosen by the couple through their locational choice of a single, place-based domicile. Some scholars even discern here a constitutional implication of the right to travel if one makes such an important interest vulnerable when an individual travels from one state to another. 89

The fact of mobility between territorial jurisdictions suggests another possible element to the analysis of recognition of same-sex marriage stateby-state. When one views the provision of same-sex marriage or a similar status as a local public good, a story about jurisdictional competition over local public goods first articulated by Charles Tiebout ${ }^{90}$ comes into focus.

87 Yes, there are problems with determining domicile.

88 KOPPELMAN, supra note 73, at 95-96.

89 On the constitutional right to travel, see, e.g., Saenz v. Roe, 526 U.S. 489 (1999); Sosna v. Iowa, 419 U.S. 393 (1975). On arguments addressing the implications for same-sex marriage of a constitutional right to travel, see, e.g., Mark Strasser, The Privileges of National Citizenship: On Saenz, Same-Sex Couples, and the Right to Travel, 52 RUTGERS L. REV. 553 (2000).

90 Charles M. Tiebout, A Pure Theory of Local Expenditures, 64 J. POL. ECON. 416 (1956). Tiebout argued that a market-like competition in local public goods would be created because residents of a 
Tiebout's analysis has occasionally been invoked to justify jurisdictional variation as to the recognition of same-sex marriage, supplying a theoretical justification for a federalism argument around same-sex marriage. ${ }^{91}$ One problem with Tiebout-type solutions has to do with the costs of exit, which can limit mobility. ${ }^{92}$ This may occur, for example, when the scale of the local jurisdictions is large, as it is in the state-by-state patchwork of samesex marriage laws. Reducing the scale to the local level might reduce this cost of exit. ${ }^{93}$ So might eliminating the scale altogether by disestablishing marriage and making its provision aterritorial and nullibietous. ${ }^{94}$

\section{B. The Aterritorial Nomos Approach}

The term "nomos" comes from the reflection by Robert Cover on the accommodation of different religious and moral communities within the American polity, in what we might call nowadays an article on cultural and moral pluralism. ${ }^{95}$ Reflecting on freedom of religion cases involving separate communities such as the Amish, Cover posited a framework for understanding that within the American multicultural framework we could account for communities whose members maintained a separate sense of identity and morality, in part through their shared stories. Cover does not especially dwell on the geographic whereness elements of such communities, though a moment's reflection will show that in the more separatist of them, there is indeed a mechanism of living physically apart and in proximity to liked-minded others. That once again suggests the relevance of my observation, found in the earliest paragraph of this essay, on the way in which identity is formed, maintained, and reproduced in daily microperformances for self and others in local communities.

local jurisdiction could relocate, and therefore local jurisdictions would compete, providing different combinations of local public goods.

91 See, e.g., Bell \& Parchomovsky, supra note 79, at 76-78, 87-88; Jennifer Gerarda Brown, Competitive Federalism and the Legislative Incentives to Recognize Same-Sex Marriage, 68 S. CAL. L. REV. 745 (1995) (exploring the economic incentive to states to be among the first to recognize same-sex marriage); F.H. Buckley \& Larry E. Ribstein, Calling a Truce in the Marriage Wars, 2001 U. ILL. L. REV. 561, 601 (proposing that same-sex couples may choose a place to live based on the jurisdiction's policy, as may opponents of same-sex marriage). See generally Solimine, supra note 78; Poirier, Cultural Property, supra note 17, at $367 \mathrm{n} .99$ (arguing that marriage is a public good); id. at 408-10 (exploring the application of Tiebout analysis to same-sex marriage); Robert M. Verchick, Same-Sex and the City, 37 URB. LAW. 191 (2005) (discussing the tension between overlapping territorial jurisdictions and different populations' contrasting cultural views towards homosexuality and same-sex marriage).

92 See generally Erin O'Hara \& Larry Ribstein, From Politics to Efficiency in Choice of Law, 67 U. Chi. L. Rev. 1151, 1162 (2000) (the costs of exit can limit its usefulness as a government disciplining device); Todd E. Pettys, The Mobility Paradox, 92 GEO. L.J. 481 (2004) (exploring mobility problems with Tiebout's theory of local jurisdictional competition in the provision of public goods).

93 As suggested for example by Schragger, supra note 67.

94 See infra Part III.B.

95 Robert Cover, The Supreme Court, 1982, Foreword, Nomos and Narrative, 97 HARV. L. REV. 4 (1983). 
Jay Michaelson has suggested that those seeking a multicultural dialogue around the contemporary Kulturkampf might profitably turn to Cover, ${ }^{96}$ and so I shall briefly, here. The idea of a nomic community is actually extraordinarily familiar. All one needs to do is set aside for a moment the concern about who or what has jurisdiction over the legal significance of marriage and ask instead who or what controls the spiritual or moral significance of marriage. It will be apparent immediately that for many, perhaps most, Americans, the answer is a church, synagogue, or similar religious institution with which they are affiliated. These are nomic communities. Not all are perhaps as thoroughgoing or apart from the world as the ones Cover scrutinized, but in matters of family morality, nevertheless, there they are. Whether marriage is sanctified or a sacrament is determined by such communities. In some religious traditions, restrictions on both marriage and divorce may be imposed apart from the territorial jurisdiction's civil rules, creating something of a dual structure to marriage for adherents of those faiths.

The basic point, though, is that we need look no further than the church down the block for an example of an aterritorial response to "Where is same-sex marriage?" Different nomic communities differ in their responses to whether to recognize same-sex marriage. We could identify strongly opposed religions such as Catholicism, the Church of Jesus Christ of Latter Day Saints, Orthodox Judaism, and evangelical Protestantism. We could identify supportive religions, such as the Society of Friends, Unitarian Universalism, the United Church of Christ, and the Reform and Reconstructionist arms of American Judaism. There is also the question of how to deal with differing viewpoints within any of these nomoi. We could identify denominations that are managing internal conflict relatively peacefully, so far-Lutherans, Presbyterians, the Conservative branch of American Judaism. We could identify those that are on the verge of sharp splits and perhaps schism, certainly the American Episcopal Church, ${ }^{98}$ perhaps United Methodists. The mechanisms of cultural dissent, in Madhavi Sunder's term, $^{99}$ are evident within these nomic communities, as all of them have to face the contemporary Kulturkampf, in one way or another.

96 Jay Michaelson, On Listening to the Kulturkampf, or, How America Overruled Bowers v. Hardwick, Even Though Romer v. Evans Didn't, 49 DuKE L.J. 1559, 1610-18 (2000).

97 For a current examination of some of the distance that Catholic and Jewish approaches to marriage make, and of their relevance to the political struggle over recognition of same-sex couples in civil marriage, see Mary Anne Case, Marriage Licenses, 89 MinN. L. REV. 1758, 1766 (2005).

98 See, e.g., Laurie Goodstein, Episcopal Split as Conservatives Form New Group, N.Y. TIMES, Dec. 4, 2008, at A1 (conservatives within the American Episcopal Church announce the formation of a new, non-territorially based "Anglican Church in North America"); Neela Banerjee, Episcopal Diocese Votes to Secede from Church, N.Y. TimES, Dec. 9, 2007, at A34.

99 Sunder, Cultural Dissent, supra note 54. 
Among the available strategies to manage conflict is exit, of course. ${ }^{100}$ This could be the exit of a particular parish or diocese from a denomination altogether; but it could also be, and more commonly is, the exit of a particular member from one nomic community, perhaps to join another. Typically, membership in such nomic communities does not depend on territorial location of members. ${ }^{101}$ The aterritoriality of these nomoi is noteworthy. It makes individual exit less costly, at least in terms of a physical move. ${ }^{102} \mathrm{We}$ could look at whatever moral structure and spiritual blessing nomic communities offer vis-à-vis marriage, as they variously define it, as competition in the provision of local public goods. In contrast to Tiebout-type local public goods, these are nullibietous public goods. They exist, but nowhere in specific; their benefits are not tied to the physical place of those who benefit from them.

There are various proposals for disestablishing marriage - that is, eliminating civil marriage altogether, and concurrently allowing nomic communities to provide for the licitness of marriage variously on their own terms. $^{103}$ (Presumably some kind of civil recognition of various kinds of households or partnership relationships would have to accompany disestablishment of marriage, because our modern administrative state depends so heavily on the family form.) Proposals for disestablishment may be motivated on the one hand by a libertarian suspicion of undue state interference in privately chosen social relations, or on the other by a typically liberal concern for separation of church and state. My own contribution, perhaps, is to suggest that disestablishment also addresses some of the problems with exit costs when we assign the definition of marriage to territorial jurisdictions. $^{104}$

100 See generally AlBERT O. HiRSChMAN, EXIT, VOICE AND LOYALTY: RESPONSES TO DECLINE IN FiRMS, ORGANIZATIONS, AND STATES (1970).

101 This is not always so. A truly separate community may require faithful adherents to move in, and some more dispersed denominations may in theory assign membership parish by parish or ward by ward based on territorial jurisdiction.

102 I do not presume to weigh the sometimes immense costs of leaving the church of one's childhood or family. And joining a different church, synagogue or meditation group may involve costly travel. But none of this is the same as having to move from one state to another to secure the desired public goods around Kulturkampf issues.

103 See, e.g., Stephen L. Carter, “Defending” Marriage: A Modest Proposal, 41 How. L.J. 215, 216 (1998) (asking "Why is the state in the business of regulating marriage at all?" and recommending serious exploration of this question); Stephanie Coontz, Taking Marriage Private, N.Y TIMES, Nov. 26, 2007, at A23; Alan M. Dershowitz, To Fix Gay Dilemma, Government Should Quit the Marriage Business, L.A. TIMES, Dec. 3, 2003, at B15; Edward A. Zelinsky, Deregulating Marriage: The ProMarriage Case for Abolishing Civil Marriage, 27 CARDOZO L. REv. 1161, 1163 (2006) ("[I]t is time to abolish civil marriage. The law should not define, regulate, or recognize marriage. Marriage ... should become solely a religious and cultural institution with no legal definition or status.").

104 This approach to the disestablishment of marriage is broached briefly in the concluding section of Poirier, Cultural Property, supra note 17, at 413; see also O'Hara \& Ribstein, supra note 92, at 1162. 
There is, however, a huge inherent downside to communities of meaning that exist nowhere and everywhere. They can be polluted, degraded, or desecrated from any quarter. The problem is perhaps encapsulated in the well-known exchange in which a congressman said essentially "Well, I don't think your same-sex marriage affects my marriage, but I know that it affects marriage generally, somehow." ${ }^{, 105}$

Here is my thumbnail sketch of the dynamics of the problem. Because aterritorial nomoi rely for their connectedness on signification, they are likely to be vigilant about cultural signals and performances, which may come from anywhere. This may be especially true when the ties that bind such a community take on universalizing and moralistic dimensions. In terms of a distinction that Mary Anne Case has proposed in a work in progress, such communities are prone to "perfectionist" claims. ${ }^{106}$ For a perfectionist, everyone must see and do things a certain way with regard to important cultural and moral matters. Such universal views leave no room for exit strategies at all. Moreover, in an age of global media access, any offensive law or performance anywhere in the world may be seen to threaten or pollute an aterritorial nomic community. One gets responses to Lawrence v. Texas ${ }^{107}$ from the other side of the world, ${ }^{108}$ and traditionalists cite the constitution of Afghanistan as an example of the universality and urgency of defining marriage as between a man and a woman. ${ }^{109}$

Indeed, if nomic communities are understood to be constituted primarily in discursive space and only secondarily in places, then we can understand how the threat of signal distortion, desecration, heresy, and pollution is an inherent possibility built into their structure. When people identify themselves and one another, and reproduce their nomic communities in daily microperformances, in what they say and do (where what they do has communicative significance), then there will always be the possibility of transgressive communication and action. Part of what will enable the community to persist over time is suppression, the policing, and elimination of unacceptable variation. The preservation of the discursive space used by a nomic community will necessarily lead to battles over censorship, desecration, transgressive performance, and the like.

105 Exchange between Rep. Barney Frank and Rep. Henry Hyde on the Defense of Marriage Act, edited version reproduced in SAME-SEX MARRIAGE PRo \& CON: A READER 225, 226 (Andrew Sullivan ed., 1st ed. 1997).

106 Mary Anne Case, On Feminist Fundamentalism (on file with author).

107 Lawrence v. Texas, 539 U.S. 558 (2003).

108 Sonia K. Katyal, Sexuality and Sovereignty: The Global Limits and Possibilities of Lawrence, 14 WM. \& MARY BILL. RTS. J. 1429, 1433-34 (2006).

109 Lynn D. Wardle, Federal Constitutional Protection for Marriage: Why and How, 20 BYU. J. PuB. L. 439, 454 (2006). 
C. Where's the Wedding?: Metonymy

Asking the place/space question about same-sex marriage can be understood to include the question of where particular same-sex weddings occur. One might need to know where the wedding is for purposes of lex loci celebrationis, which will help to determine whether the marriage is valid. And of course, same-sex couples will plan weddings in locations that recognize same-sex marriage or some marriage substitute, thus entailing wedding tourism in addition to the occasional permanent relocation of such couples.

Issues around the location of the wedding can also involve conflicts over access to specific places that have special significance as discursive spaces. Consider a current controversy in Ocean Grove, New Jersey. Ocean Grove is an interesting place, founded in 1869 as a United Methodist Camp Meeting and chartered by the state of New Jersey in $1870 .^{111}$ Its ecclesiarchical government - a city governed by a corporate church-related organization-was overturned by the New Jersey Supreme Court in $1979 .{ }^{112}$ But the Camp Meeting Association continues to own the land and many public buildings, including specifically a beachfront Pavilion. ${ }^{113}$ Many weddings have been celebrated in this lovely location. In the past couple of decades, though, the population of Ocean Grove changed, with many lesbian and gay couples moving there. After enactment of New Jersey's civil union law in December 2006, two lesbian couples sought to book the Pavilion for their civil union ceremonies. ${ }^{114}$ They were turned down, because the United Methodist Church does not recognize same-sex unions. ${ }^{115}$ The couples filed civil rights complaints with the state's Division on Civil Rights under the state's LAD, applied to the Pavilion as a public accommodation. $^{116}$ The Camp Meeting Association retaliated with a federal lawsuit seeking an injunction on the basis that the state's investigation violated various constitutional rights of the Camp Meeting Association. In November 2007, the federal district court dismissed the Camp Meeting Association's complaint under the doctrine of Younger abstention. ${ }^{117}$ The state investigation is ongoing. ${ }^{118}$

110 See, e.g., Brown, supra note 91.

111 Ocean Grove Camp Meeting Ass'n of the United Methodist Church v. Vespa-Papaleo, 2007 U.S. Dist. LEXIS 82577 at $* 2$ (Nov. 7, 2007).

112 State v. Celmer, 404 A.2d 1 (N.J. 1979).

113 Ocean Grove, 2007 U.S. Dist. LEXIS at *2.

$114 I d$. at $* 3$.

115 Id.

116 Id.

117 Ocean Grove Camp Meeting Ass'n of the United Methodist Church v. Vespa-Papaleo, 2007 U.S. Dist. LEXIS 82577 (Nov. 7, 2007) (applying Younger v. Harris, 401 U.S. 37 (1971)).

118 For helpful short accounts of the controversy, see Jill P. Capuzzo, Civil Union Dispute Pits Methodist Retreat Against Gays Who Aided in Its Rebirth, N.Y. TIMES, Sept. 3, 2007; Julia Vitullo- 
The resolution of the Ocean Grove dispute may ultimately turn on whether the Pavilion is within the meaning of an exception in the LAD for real property owned by religious organizations. ${ }^{119}$ It may turn on whether the private status of the Pavilion has been waived by the Camp Meeting Association because it dedicated the Pavilion to public use, in practice (a kind of prescriptive publicness) and/or through repeated formal applications for tax exemptions that include the Pavilion as part of park-like space and that stated that the Pavilion was open to the public. It might turn on whether exempting the Pavilion from the Law Against Discrimination constitutes an establishment of religion; or whether refusing to exempt the $\mathrm{Pa}$ vilion constitutes an interference with the free exercise of religion. The case might also turn ultimately on the application of the doctrine of expressive association, as articulated in Boy Scouts of America v. Dale. ${ }^{120}$

Notable here is the mechanism of the controversy. It is Kulturkampf played out in a particular physical place and discursive space, with a privately-owned building standing in for a strict Methodist nomic community, and a civil union ceremony standing in for the principle of same-sex marriage, challenging the nomic community's restrictive approach to marriage. I will call this conflict an example of metonymy, metonymy being a rhetorical trope where one thing is used to stand in for another, related thing. ${ }^{121}$ The Pavilion has become, because of its longstanding use in the community as a site for weddings, not only a place, but a contested discursive space in which the broader topic of marriage equality is addressed. From the lesbian couples' viewpoint, especially in light of Lewis v. Harris, ${ }^{122}$ civil unions are supposed to be just like marriages, and civil union ceremonies should be permitted to occur in any public places and spaces, any place of public accommodation. Moreover, as a public place in which weddings

Martin, On the Boardwalk: Must civil unions be performed on religious property?, WALL ST. J., Oct. 12, 2007, available at http://www.opinionjournal.com/taste/?id=110010726\&mod=RSS_Opinion_ Journal\&ojrss=frontpage. For a history of the Ocean Grove Camp Meeting Association, see TroY Messenger, Holy Leisure: Recreation And Religion in God’s SQuARe Mile (2000); Glenn Uminowicz, Recreation in a Christian America: Ocean Grove and Asbury Park, New Jersey, 1869 - 1914, in HARD AT PlAY: LEISURE IN AMERICA, 1840-1940 8 (Kathryn Grover ed., 1992).

119 Within the definition of "real property" in N.J.S.A. 10:5-5(n), one finds: "Nothing herein contained shall be construed to bar any religious or denominational institution or organization, or any organization operated for charitable or educational purposes, which is operated, supervised or controlled by or in connection with a religious organization, in the sale, lease or rental of real property, from limiting admission to or giving preference to persons of the same religion or denomination or from making such selection as is calculated by such organization to promote the religious principles for which it is established or maintained." In the ongoing administrative proceeding, however, the plaintiffs and the state take the position that this exception applies to the sale or long-term rental of real estate, but not to the type of short term rental characteristic of public accommodations.

120 Boy Scouts of Am. v. Dale, 530 U.S. 640 (2000).

121 For example, "The pen is mightier than the sword" is not about pens and swords, but about public media and dialogue on the one hand and military and police force on the other.

122 Lewis v. Harris, 908 A.2d 196 (N.J. 2006). 
have routinely occurred and been visible to the local Ocean Grove community, the Pavilion would be especially desirable, apt, and normalizing.

In contrast, the Camp Meeting Association views the rental of the Pavilion for a civil union ceremony as tantamount to an endorsement of civil unions. Consequently, it views its exclusion of the couples from the Pavilion place as expressive or religious. ${ }^{123}$ Whether the Camp Meeting Association is entitled to the religious real property exception, or is protected by some broader constitutional principle of free exercise, free speech, or expressive association, the principle involved is hardly foreign to New Jersey law. The exception in the LAD for religiously owned property explicitly recognizes the connection between religiously owned property and religious expression through exclusion in at least some circumstances.

D. Microperformances of Married Status: The Traditional and the Transgressive

When couples appear in public - especially couples of about the same age, not related by blood, and especially when it is a man and a woman many people will make assumptions about whether they are emotionally and physically intimate-whether they are pair-bonded and coupling sexually. They may want to know if they are married. And they will look for clues and hints in the small interactions between the members of these couples.

Sometimes others' conclusions about relationship and status are mistaken. When I travel with my sister, we present as a family unit. We are clearly long-term friends, intimate, and comfortable with one another. People almost always assume we are husband and wife.

Nowadays, GLBT issues are salient enough to make the nature of same-sex couples' microperformances a matter that most folks will notice and will admit to noticing. When a same-sex couple appears in public, of the same age more or less, and appears emotionally and perhaps physically close, people may not know quite what to think or do. Are they homosexual? Are they physically intimate? Are they life partners? Are they, perhaps, even, legally married/united/partnered in the eyes of some territorial jurisdiction, husband and husband or wife and wife? This may make a difference to those who observe such couples, in terms of how they assess the couple's identity and how they interact with the couple and the couple interacts with them.

Marc Fajer noted some time ago that when two "real men" behave in public as intimate friends, people may well assume that they are gay and

123 Unless it has made the Pavilion public in a permanent way that waives its future right to exclude. 
sexually intimate. ${ }^{124}$ Fajer focuses on sexual orientation. These days the couple's relationship and status are also likely to be of interest. In part, this is because knowing who is married is important to us, for all sorts of reasons. In a traditional view, the status of marriage sorts out licit relationships, and ones in which sexual activity in particular is licit, from other less legitimate relationships and pursuits. ${ }^{125}$ The status of marriage also sorts out relationships that may produce legitimate children and that do produce other new kinship relationships. It creates all sorts of benefits and obligations, as between the couple and as between one spouse and third parties. But how do we know when a couple that appears to be intimate is in fact married? In addition to all the behavioral signs, we rely on the wedding band, perhaps especially, and the names and language they use to refer to one another (to each other and to third persons). All of these help us to sort out the nature of the relationship without ever asking to see the legal papers.

The visible presence of an apparently intimate same-sex couple is like the mere presence of Mr. Dale in the Monmouth County Boy Scouts troop as an avowed homosexual, or of a GLBT group with an identifying banner in a St. Patrick's Day parade. It lays claim to the normal status that visible appearance as a married couple offers to different-sex couples. At the same time, because appearance as a same-sex couple makes homosexuality visible without shame, it can be perceived by traditionalists as a transgressive appropriation of the status of a married couple (I mean to include here both legal status and whatever social acceptability comes with married couple status). Thus, small, visible appearances as a married couple threaten to reconfigure social norms and categories. ${ }^{126}$

Consider Shahar v. Bowers. ${ }^{127}$ In that case, a law student held herself out to be engaged, then married her female partner in a Jewish Reconstructionist ceremony. They were not legally married, of course, as the states of Georgia (where she lived) and South Carolina (where the ceremony occurred) did not permit it. Nevertheless, her offer of employment with the state Attorney General's office was withdrawn. The Attorney General's

124 See, e.g., Fajer, supra note 19; Jennifer B. Lee, What Do You Call Two Straight Men Having Dinner?, N.Y. TIMES, Apr. 10, 2005, §9, p. 1 (discussing how two men socializing together without involving sports or business will lead to questions about sexual orientation). For some kinds of coupled microbehaviors, the interpretation depends on further contextual details. Fajer points out that companionship in contexts such as sports or business are sufficiently masculine to lift the suspicion of homosexuality. Eating quiche, as in his title, seems suspiciously effeminate or foreign. Thanks to Michael Poreda for insisting on this point.

125 Cf. Ariela R. Dubler, Immoral Purposes: Marriage and the Genus of Illicit Sex, 115 YALE L.J. 756 (2006) (exploring the ways in which marriage has been understood to cure illicit sex).

126 To be sure, Ariela Dubler argues that Lawrence v. Texas, 539 U.S. 558 (2003), in fact represents a significant shift away from making marriage the cure for illicit sex. Id. at 809-10. The sexual relations in Lawrence were not and could not lead to marriage, yet were treated as at least somewhat licit if they occurred in private.

127 Shahar v. Bowers, 114 F.3d 1097 (11 ${ }^{\text {th }}$ Cir. 1997) (en banc). 
reasons, which prevailed, were based on a government employer's right to balance an employee's behavior and continued employment, especially in a sensitive and public job such as law enforcement. The Attorney General believed that the appearance of Shahar as married to another woman would create questions around conflicting interpretations of Georgia law, would affect the public credibility of the state's interpretations of state law, would interfere with working relationships in the department, and that it indicated poor judgment on Ms. Shahar's part. ${ }^{128}$

I am not concerned for present purposes with the doctrinal reasons adopted in the majority or argued in the dissent. What interests me here is why and how Ms. Shahar's holding herself out as married was problematic. That it was problematic to the court is indicated from the very first footnote, in the very first sentence of the opinion. There, the court distinguishes between Shahar's religious marriage and wedding, which it puts in scare quotes, and marriage without scare quotes, which the court used "to indicate legally recognized heterosexual marriage." 29 There is what Judge Godbold in dissent calls a "duality of meaning" around marriage. ${ }^{130}$

Shahar held the duality of meaning about her marriage differently from the Attorney General. She understood that she was married, but not legally married. "According to Shahar, though the State of Georgia does not recognize her 'marriage' and she does not claim that the 'marriage' has legal effect, she and her partner consider themselves to be "married.'"

On legal forms, Shahar described herself as engaged. She then participated in a traditional (except for the same-sex part) Jewish Reconstructionist wedding before a congregation of 250 people in a public park. ${ }^{132}$ The couple exchanged wedding bands - a permanent and visible symbol of marriage, as the court recognized explicitly. ${ }^{133}$ But her actions did not stop there. The court catalogs several other ways in which Shahar "held herself out as "married.","134 She and her partner changed their names so that they would have the same last name. They obtained a married rate on insurance. They owned a house and cohabited in it. As the court stresses, "these things were not done secretly, but openly." "Th5 court concluded that "[e]ven if Shahar is not married to another woman, she, for appearance purposes,

128 Id. at 1101.

$129 I d$. at 1099 n.1.

130 Id. at 1118, 1121 (Godbold, J., dissenting).

131 Id. at 1100.

132 Id. Judge Godbold's dissent reproduces several paragraphs from the opinion below and discusses in great detail how Shahar's relationship and wedding adhered to traditional Jewish beliefs and practices. Id. at 1119-20.

133 Id. at 1107.

134 Id.

135 Id. 
might as well be." 136 Shahar "became-and remains for all to see- 'married.", 137

Shahar argued to the court that her wedding and marriage occurred in a non-employment related context. ${ }^{138}$ Presumably then, they should not have mattered to her employer. We have seen this move before-an attempt to split discursive space. The court-at least the majority-didn't buy it. It gave the employer great deference around the determination of how much Shahar's performances of marriage would infringe on her effectiveness and the effectiveness of the office. Just as in Boy Scouts of America v. Dale, ${ }^{139}$ a GLBT individual was not allowed by the court to contain or limit the significance of her/his identity, once it had been publicly revealed.

Judge Godbold's dissent chastises the majority on this point. In light of the "duality of meaning" of marriage, he says that the majority erred by adopting only one view. ${ }^{140}$ It should have realized that there was a nonlegal kind of marriage at issue in the case, a religiously-motivated view and practice, and should have required the Attorney General to investigate and balance that view and practice properly, instead of acting in ignorance of it. $^{141}$

Shahar's problematic appearance of being married occurred against an increasingly vexed backdrop: "ongoing controversy in Georgia about homosexual sodomy, homosexual relations, and other issues...." 142 A footnote lists matters ongoing in Georgia state courts during the pendency of the Shahar litigation, including such issues as a gay father's visitation rights, municipal authority under state law to register domestic partners, the relevance of a former spouse being in a same-sex relationship to the other former spouse's alimony, and whether group health insurance rates could be made available to domestic partners. ${ }^{143}$ Moreover, although the court does not mention it, surely many people would have been aware of the stir caused by the Hawaii same-sex marriage litigation and subsequent state constitutional amendment. Both piecemeal and wholesale recognition of same-sex couples were in the air.

Although Shahar's wedding and marriage were undertaken with all sincerity within a recognized variant tradition of the Jewish faith, one could argue that they are still transgressive or parodic versions of marriage. That is certainly how the Attorney General saw them, and how he thought that

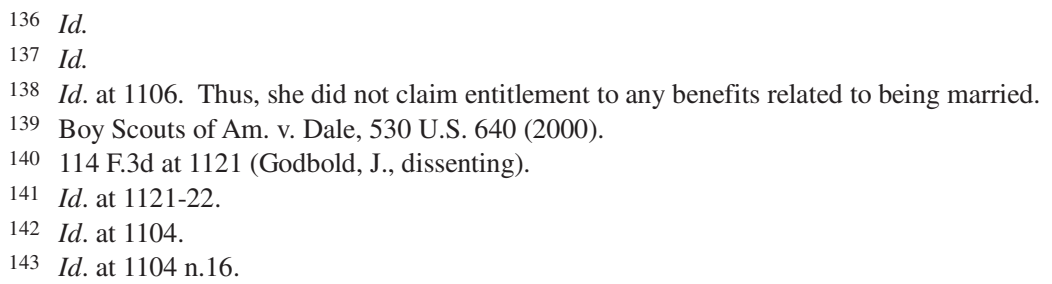


the public would understand them. Traditionalists might well understand Shahar's performances of being married to undermine not only Shahar's own credibility as an agent of the state, and the credibility of the office of the state Attorney General, but also the institution of marriage itself. Generally speaking, when same-sex couples adopt the visible microperformances of being married, their intent might be mixed, as might be the effects of their actions. In seeking to attain the normalizing status of marriage, they perforce do marriage differently, and so their actions will tend to redefine it. Whether visible microperformances of married status by samesex couples reaffirm or significantly undermine the underlying, traditional, gendered structure of the institution of marriage remains to be seen.

To answer the question "Where is same-sex marriage?" as to microperformances of married status, the signs and gestures of marriage can occur anywhere, from the wedding ring on a finger, to one woman calling the woman beside her her wife, to assertions of legal relationship in the emergency room, to the presentation as a couple to the insurance agent or the travel agent, to simply living together and taking turns walking the dogs, and to putting out the recycling suffices. The locations within daily life where marriage is performed and reaffirmed are myriad. So too are the places where same-sex couples, whether or not they have yet achieved the name and status of marriage, can shift social practice bit by bit.

\section{CONCLUSION: ASKING THE Place/SPACE Question WHERE IDENTITY PERFORMANCE IS CONCERNED}

When thinking about identity, especially identity as iterated performance, we sometimes overlook the importance of the places and spaces in which people must interact around identity. Part III supra provides an example of what happens when we "ask the place/space question" "144 with regard to same-sex marriage.

As Katharine Bartlett has pointed out, "A question becomes a method when it is regularly asked." 145 Systematically asking the place/space question could enrich the theory, doctrine, and practice around stigmatized identities.

First, it might encourage us to turn more regularly to any of several disciplines that have sought to address the mechanisms of subordination in terms of identity performances in specific places and spaces. For example, in a forthcoming symposium article, I draw on the dramaturgical approach to analyzing performances of the self from sociologist Erving Goffman, on

144 Cf. Katharine T. Bartlett, Feminist Legal Methods, 103 HARV. L. REV. 829, 831, 837-49 (1990) (arguing that repeatedly "asking the woman question" becomes a method that furthers important feminist political goals).

145 Id. at 837. 
legal academic Kenji Yoshino's account of identity performance, and on some of the writings of philosopher and cultural critic Judith Butler, exploring how their insights apply to disputes over the visibility of same-sex couples. ${ }^{146}$ Generally speaking, "Without an understanding of sociological issues of belonging, recognition and solidarity we cannot adequately address the political issues of status, rights and equality." doctrinal consequence of developing a method of asking the place/space question relating to identity might be a fuller development of what Nan Hunter has called the matter of expressive identity. ${ }^{148}$ While conflicts about GLBTQ visibility are sometimes framed doctrinally in terms of traditionally protected First Amendment speech or conduct, ${ }^{149}$ this approach is often somewhat of a tangent to important controversies, for it does not quite get at the way in which visibility without shame, in specific places and spaces, is the underlying contested issue. Legal scholars have touched on this matter from various angles, ${ }^{150}$ but the approach does not seem particularly well developed at this time. A focus on the place/space aspects of identity and visibility could help to understand better and perhaps to reformulate doctrinally a series of important cases about the compelled sharing of places and spaces where identity is at issue. ${ }^{151}$ It might also serve to develop a differen-

146 Marc R. Poirier, Microperformances of Identity: Visible Same-Sex Couples and the Marriage Controversy, 15 WASH. \& LEE J. CIV. Rights \& SOC. JUSTICE (forthcoming 2009).

147 ENGIN F. Isin \& PATRICIA K. WoOd, CitIZENShiP AND IDENTITY 13 (1999).

148 Nan D. Hunter, Expressive Identity: Recuperating Dissent for Equality, 35 HARV. C.R.-C.L. L. REV. 1 (2000).

149 See, e.g., Fricke v. Lynch, 491 F.Supp. 381 (D.R.I. 1980) (high school student must be allowed to bring same-sex date to prom as a matter of First Amendment right).

150 See, e.g., David B. Cruz, "Just Don't Call It Marriage”: The First Amendment and Marriage as an Expressive Resource, 74 S.CAL. L. REV. 925 (2001); David B. Cruz, The New "Marital Property": Civil Marriage and the Right to Exclude, 30 CAP. L. REV. 279 (2001); William N. Eskridge, Jr., A Jurisprudence of "Coming Out": Religion, Homosexuality, and Collisions of Liberty and Equality in American Public Law, 106 Yale. L.J. 1411 (1997); Nan D. Hunter, Accommodating the Public Sphere: Beyond the Market Model, 85 MinN. L. REV. 1591 (2001); Hunter, Expressive Identity, supra note 148; Nan D. Hunter, Escaping the Expression-Equality Conundrum: Toward Anti-Orthodoxy and Inclusion, 61 Oнio ST. L.J. 1671 (2000); Sunder, Authorship, supra note 23. Timothy Zick has recently embarked on a rethinking of First Amendment doctrine in terms of control of what he calls "special tactics" and microgeographies. See, e.g., Timothy Zick, SPEECH OUT OF DoORs: PRESERVING FiRST AMENDMENT Liberties IN PUBlic Places (2009); Timothy Zick, Space, Place, and Speech: The Expressive Topography, 74 GeO. WASH. L. REV. 439 (2006); Timothy Zick, Speech and Spatial Tactics, 84 TEX. L. REV. 581 (2006); Timothy Zick, Property, Place, and Public Discourse, 21 WASH. U. J. L. \& PUB. POL. 173 (2006). While more focused on traditionally protected First Amendment speech and activities than on visibility of identity, Zick's work is important because of its insistence on the relevance of interpersonal interactions in places and spaces to First Amendment analysis.

151 E.g., Rumsfeld v. Forum for Academic \& Institutional Rights, 547 U.S. 47 (2006); Boy Scouts of America v. Dale, 530 U.S. 640 (2000); Hurley v. Irish-American Gay, Lesbian, and Bisexual Group of Boston, 515 U.S. 557 (1995); Roberts v. United States Jaycees, 468 U.S. 609 (1984); PruneYard Shopping Center v. Robins, 447 U.S. 74 (1980); Hudgens v. National Labor Relations Board, 424 U.S. 507 (1976); Heart of Atlanta Motel, Inc. v. United States, 349 U.S. 241 (1964); Marsh v. Alabama, 326 U.S. 501 (1946); Gay Rights Coalition of Georgetown University Law Center v. Georgetown University, 536 A.2d 1 (D.C. Cir. 1987) (en banc). 
tiated theory of claims of a right to appearance, based on the identity at stake and the specific place or space within which the right is asserted. ${ }^{152}$

Asking the place/space question systematically might also serve to bridge the gap between broad discussions of "full citizenship" and an array of more focused doctrines that mediate between specific practices of exclusion and broad claims of citizenship. ${ }^{153}$ By way of introductory background, for perhaps a couple of decades now, various debates about politics, human rights, political participation, and identity have been phrased in terms of "citizenship." 154 The term is used in many ways, with little uniformity. Linda Bosniak has called citizenship "a very chaotic field.", Brenda Cossman, writing specifically about sexual citizenship, agrees that there is little uniformity in the usage. ${ }^{156}$ Both authorities, however, describe a fourfold taxonomy of meanings of "citizenship": citizenship as legal status; citizenship as access to political, social and civil rights; citizenship as participation in political processes; and citizenship as individual and group identity. ${ }^{157}$

152 For example, Tristin Green analyzes the complicated issue of workplace appearance rules in terms of expressions by some workers of stigmatized identities, and proposes to differentiate among claims to a right of appearance in the workplace on the basis of the effect that allowing certain types of appearances will have in the reduction of stereotyping and prejudice. Tristin K. Green, Discomfort at Work: Assimilation Demands and the Contact Hypothesis, 86 N.C. L. REV. 379 (2008); see also Gowri Ramachandran, Antisubordination, Rights, and Radicalism, 40 CONN. L. REV. 1045, 1073-74 (2008); Gowri Ramachandran, Freedom of Dress: State and Private Regulation of Clothing, Hairstyle, Jewelry, Makeup, Tattoos, and Piercing, 66 MD. L. REV. 11 (2006); cf. Devon W. Carbado \& Mitu Gulati, Working Identity, 85 CORNELL L. REV. 1259 (2000) (providing a foundational analysis of identity performance in the workplace); Note, Lessons in Transcendence: Forced Association and the Military, 117 HARV. L. REV. 1981 (2004) (exploring within the context of the military the effects compelled copresence and visibility on racial stereotyping, and arguing that a similar effect would occur if the military's current "Don't Ask, Don't Tell" policy were repealed ).

153 This discussion of citizenship stems from my recent participation in Southern Methodist University's Dedman School of Law's Colloquium on Law and Citizenship, and to conversations in that context with Rose Cuison Villazor and Maureen Armour. I thank them for their astute insights. Conversations with my colleague Alice Ristroph have also been most helpful.

154 In United States constitutional theory one important articulation seems to be Kenneth Karst's broad argument in favor of a right of "equal citizenship" extrapolated from specific holdings and constitutional terminology and history. Kenneth L. Karst, The Supreme Court 1976 Term, Foreword: Equal Citizenship Under the Fourteenth Amendment, 91 HARV. L. REV. 1 (1977); see also KENNETH L. KARST, Belonging to AMERICA: EQUAL Citizenship AND the Constitution 2-3 (1989) (summarizing the idea of equal citizenship); Denise C. Morgan \& Rebecca E. Zietlow, The New Parity Debate: Congress and Rights of Belonging, 73 U. CINN. L. REV. 1347, 1394-405 (2006) (sketching the history of various constitutional rights that together constitute a more general right of belonging).

155 Linda Bosniak, Citizenship Denationalized, 7 InD. J. Global LEgal Stud. 447, 455 (2000).

156 Brenda Cossman, SeXual Citizens: The Legal and Cultural Recognition of SeX AND BELONGING 3 (2007).

157 Bosniak, Citizenship, supra note 155, at 456-88; CoSSMAN, supra note 156, at 3-5; accord, Seyla Benhabib, The Claims of Culture: Equality and Diversity in the Global ERA 162-65 (2002); Linda Bosniak, The Citizen And the AliEn: Dilemmas of Contemporary Membership 18-20 (2006). Benhabib clearly demarcates the last three types of citizenship, and her discussion of the 
Bosniak and Cossman agree that all these types of usages have in common some concept of "membership." of "equal citizenship" as membership or inclusion often requires a kind of step-down transformation into more specific doctrines and categories in order to address particular controversies involving particular individuals, even though these are also about citizenship. As Cossman writes, citizenship "invok[es] the ways that different subjects are constituted as members of a polity, the ways they are, or are not, granted rights, responsibilities, and representations within that polity, as well as acknowledgement and inclusion through a multiplicity of legal, political, cultural, and social discourses." time. Carl Stychin agrees. "Citizenship is frequently grounded in a normative discourse of 'civic inclusion,' and citizenship provides the framework within which to make many legal claims.",160

Marriage is one such practice of citizenship, ${ }^{161}$ and the exclusion of same-sex couples from the institution of marriage does create an experience of second-class status. ${ }^{162}$ Asking the place/space question about same-sex marriage, as I have done in this essay, illuminates specific and intersecting levels of the marriage controversy. Exclusion from marriage is, however, only one of many kinds of exclusion that GLBTQ folk face. If a general sense of membership is the overarching issue raised by invoking "citizenship", we must also talk about exclusion of GLBTQ folk from many public and private institutions in addition to marriage: the military, adoption and foster parenting (in a few states), hate crime protection (in some states), protection from discrimination in employment, housing, and public accommodations (in many states and in federal law), visibility in public sex education (in many states), AIDS health care and education work (to some extent, in some states), parades public and private (in some places), private civic institutions (notably the Boy Scouts), the wedding announcements on the society page, many religious institutions, and (in some places) the prom. Exclusion from these institutions creates a sense of inequality, degradation,

problematic distinction between foreigners and nationals, in this passage and elsewhere in her book, relies on the first.

158 BOSNIAK, The Citizen and the Alien, supra note 157, at 18; Cossman, supra note 156, at 5.

159 Cossman, supra note 156 , at 5.

160 Carl F. Stychin, Governing Sexuality: The Changing Politics of SeXuality and LaW REFORM 7 (2003).

161 See, e.g., Angela Harris, Loving Before and After the Law, 76 FordHAM L. REv. 2861, 2861 (2008) (applying Bosniak's fourfold taxonomy of citizenship to marriage).

162 See, e.g., Kerrigan v. Commissioner of Public Health, 957 A.2d 407, 418 (Conn. 2008); In re Opinions of the Justices to the Senate, 802 N.E.2d 565, 570, 571 (Mass. 2004); Goodridge v. Department of Public Health, 798 N.E.2d 941, 948 ( Mass. 2003); David S. Buckel, Lewis v. Harris: A Settled Question and an Open Question, 59 Rutgers L. Rev. 221, 228-29 (2007); Michael S. Wald, Same-Sex Couple Marriage: A Family Policy Perspective, 9 VA. J. SoC. PoL. \& L. 291, 338 (2001). 
and outside status. ${ }^{163}$ Access to all these desirable institutions would, in various ways, confer a sense of belonging.

In terms of developing legal challenges to exclusions, doctrinally we can generate quite a long list of general, sometimes truly vague terms we might invoke to address citizenship or membership. ${ }^{164}$ Some are specifically in the federal constitutional-liberty, property, due process, equal protection, privileges and immunities (federal and state varieties). At least one more is somewhere in there sort of-privacy. Perhaps the term "citizenship" itself has some independent clout. ${ }^{165}$ Other terms not literally written in the United States constitution are certainly understood to be at issue and perhaps can be found in other (state or foreign) constitutions-dignity, respect, belonging, membership, removal of stigma, anti-caste, antisubordination. In addition we have available many more specific doctrines: antidiscrimination laws applied in public accommodations, employment and housing contexts; disability law; rights of appearance; language rights; First Amendment doctrines in various contexts; election law; education law; labor law; zoning and land use disputes, in some contexts; ${ }^{166}$ in some contexts antitrust; even perhaps the public trust doctrine. ${ }^{167}$

We can use the place/space question to develop a tiered description of the praxis of challenging various exclusions that create and maintain a sense of second-class citizenship. Transgressive presence or visibility violates an exclusion in a specific context and at a specific place and space. One or more of a number of legal doctrines can then be mobilized to challenge the specific practice of exclusion. Behind the specific practice of exclusion and the potential doctrinal challenge there lies a generalized con-

163 See generally KARST, Belonging to America, supra note 154, at 4 (discussing how exclusions on the basis of membership in subordinated groups affect each person's sense of self and identity). As Kenneth Karst explains, the effect is cumulative, as socially organized "degradation ceremonies" are "repeated day after day in a hundred ways ...." Id.

164 As Kenneth Karst points out, "The very act of filing a lawsuit implicitly affirms that the plaintiffs and defendants share membership in a community." KARST, Belonging to America, supra note 154, at 4 .

165 See, e.g., Rebecca E. Zietlow, Belonging, Protection and Equality: The Neglected Citizenship Clause and the Limits of Federalism, 62 U. PITT. L. REV. 681 (2000) (arguing that a federal constitutional citizenship jurisprudence is emerging that recognizes rights of belonging, protection equality; and that Congress has the power under the constitution's Citizenship Clause to enact further protections at the federal level, in view of resistance at the state level).

166 See, e.g., Poirier, Federalism, supra note 80, at 417-18 (discussing attempts to use local land use regulation to exclude Muslims from visibility in a Toronto neighborhood, described in Engin F. Isin \& Myer Siemiatycki, Making Space for Mosques: Struggles for Urban Citizenship in Diasporic Toronto, in Race, Space, AND the LaW: UnMapping A White SeTtler Society 185 (Sherene H. Razack ed. 2002)).

167 See Marc R. Poirier, Modified Private Property: New Jersey's Public Trust Doctrine, Private Development and Exclusion, and Shared Public Uses of Natural Resources, 15 SOUTHEASTERN ENVT'L L.J. 72, 118 (2006) (arguing that the public trust doctrine can be used as a covert substitute for other antidis-crimination doctrines). 
cept of membership and citizenship, which often informs our intuition of injustice and unfairness. An effective argument to a judge (or to the legislature, or in the court of public opinion) for rejecting specific practices of exclusion can thus be understood to occur on three levels simultaneously: place/space, doctrine, and citizenship/membership.

Social and legal shifts in smaller and more specific practices of exclusion sometimes merge together to create a stronger sense of full citizenship and participation in a wide range of societal institutions. I discussed this process in terms of piecemeal and wholesale approaches to marriage equality in a recent article. ${ }^{168}$ Citizenship arguments extrapolate from specific legal changes invalidating specific practices of exclusion into a broader theory of change, moving towards equal citizenship. ${ }^{169}$

Kenneth Karst, quoting Helen Merrell Lynd, writes "Some kind of answer to the question Where do I belong? is necessary for an answer to the question Who am I?" ${ }^{170}$ I take his point literally, at least in part. Methodically asking the place/space question around issues of stigmatized identity offers several advantages. It encourages us to explore potentially fruitful interdisciplinary synergies to develop a better account of ongoing processes that stigmatize and subordinate certain identities. It encourages development of a better doctrinal account of the problem of expressive identity. And it can provide a better theory for the praxis of challenging stigmatized identities through specific acts of transgressive presence and visibility, and a perhaps a better explanation of how piecemeal legal victories can lead to wholesale ones.

168 Poirier, Piecemeal, supra note 11.

169 Karst, Supreme Court, supra note 154; see also Suzanne B. Goldberg, Constitutional Tipping Points: Civil Rights, Social Change, and Fact-Based Adjudication, 106 ColuM. L. Rev. 1955 (2006).

170 KARST, Belonging to America, supra note 154, at 4 (quoting HeLEN MERRELL LyND, ON SHAME AND THE SENSE OF IDENTITY 210 (1958)). 